\title{
A CULTURE MEDIUM FOR TRICHOMONAS VAGINALIS DONNÉ AND SPECIES OF CANDIDA
}

\author{
BY \\ J. G. FEINBERG* AND M. JOAN WHITTINGTON \\ From the Lister Institute of Preventive Medicine, London, and the London Hospital, Whitechapel, \\ London
}

(RECEIVED FOR PUBLICATION NOVEMBER 28, 1956)

The laboratory methods usually employed for detecting Trichomonas vaginalis in secretions are the microscopic examination of wet films or fixed, stained smears, and the culture of the parasites in artificial media. In recent years the cultural method has become more widely used as an aid in the diagnosis of trichomoniasis. Different culture media have been employed for this purpose with varying degrees of success, and this paper describes a medium which seems particularly suitable, because it is cheap, easy to prepare and use, and keeps well.

During the past 40 years many attempts have been made to grow $T$. vaginalis in a variety of media. At first simple liquid bacteriological media were used (Lynch, 1915; Reuling, 1921 ; Fischer, 1935, for example). Richer media of the type used by Boeck and Drbohlav (1925) have also given good results (Andrews, 1929 ; Hawes, 1947 ; Whittington, 1951, for example). All these media had the disadvantage of favouring the growth of the accompanying bacteria as well as that of the trichomonads. Johnson and Trussell (1943) and Sprince and Kupferberg (1947) used elaborate media for maintaining bacteria-free cultures of $T$. vaginalis. The value of these media for diagnostic purposes is unknown, however, and they are too complex and expensive for ordinary routine work. McEntegart (1952) simplified Johnson and Trussell's (1943) formula for use in his studies on $T$. vaginalis, and Feinberg (1953) substantially modified McEntegart's medium and succeeded in growing the parasites in large numbers for experimental work. A further modification of this medium by Feinberg was suggested for use in routine diagnostic work, and the present investigation has been carried out to assess its value.

\footnotetext{
*During the tenure of a U.S. Public Health Service Research Fellowship of the National Microbiological Institute.
}

\section{Culture Medium}

The formula of this medium is:

\begin{tabular}{|c|c|c|c|c|}
\hline Proteolysed liver $\dagger$ & & $\cdots$ & . & $25.0 \mathrm{~g}$ \\
\hline Sodium chloride & & . & . & $6.5 \mathrm{~g}$ \\
\hline Dextrose . & . & . & . & $5.0 \mathrm{~g}$ \\
\hline Inactivated horse & serum & . & . & $80.0 \mathrm{ml}$ \\
\hline Distilled water & . & . & . & $1,000.0 \mathrm{ml}$ \\
\hline Penicillin & . & . & $\cdots$ & $1,000,000$ units \\
\hline Streptomycin & .. & $\ldots$ & .. & 500,000 \\
\hline
\end{tabular}

The solid components are dissolved in the distilled water, the serum added, and the $p \mathrm{H}$ adjusted to 6.4 by adding $\mathrm{N} / 1$ sodium hydroxide (about $9 \mathrm{ml}$. per litre of medium). The mixture is sterilized by Seitz filtration and stored in screw-capped bottles in a refrigerator.

In a diagnostic medium some method of suppressing the bacteria, which would otherwise overgrow the trichomonads, is desirable. Antibiotics serve this purpose admirably, 1,000 units of penicillin and 500 units of streptomycin per ml. of medium being an effective concentration. No deterioration of the antibacterial powers of this culture medium is evident after three months' storage in a refrigerator at $+4^{\circ}$ to $+5^{\circ} \mathrm{C}$.

\section{Sources of Clinical Material}

The patients from whom secretions were obtained were men and women attending the Venereal Diseases Department of the London Hospital (the Whitechapel Clinic), and women attending the Gynaecological Out-patient Department of the same hospital from June, 1954, to July, 1956.

Samples of vaginal secretions were collected in small sterile plastic spoons (Jackson, Malleson, Stallworthy, and Walker, 1948). After a fresh smear had been made and examined microscopically, the remainder of the sample was inoculated into about $7 \mathrm{ml}$. of the warmed culture medium in a $6 \times \frac{5}{8}$ in. test tube.

Urethral specimens from the men were obtained by Lanceley's (1954) method of gently rubbing the surface of the urethra with a platinum loop. Part

t" Panmede" brand, in powder form, obtained from Messrs. Paines and Byrne, Ltd., Pabyrn Laboratories, Greenford, Middlesex. 
of the material thus obtained was inoculated into smaller tubes $\left(3 \times \frac{1}{2}\right.$ in.) containing 2 to $3 \mathrm{ml}$. of the medium, and the rest examined microscopically.

Voided urine from both male and female patients was centrifuged, and the deposit examined microscopically and cultured in the small tubes of medium.

For direct microscopic examination of specimens, wet smears were used in preference to fixed, stained preparations because it has been found more efficient (Whittington, 1957).

The cultures were incubated immediately after inoculation at $36^{\circ} \mathrm{C}$. for four or five days and examined microscopically three times during that period. It was found desirable to centrifuge the cultures before examining them, as if only a few trichomonads are present they may escape detection in a sample taken from the tube without previous spinning.

\section{Results}

The results of comparing the detection of $T$. vaginalis in fresh smears and in cultures of specimens from 207 men and 563 women are given in Table I.

TABLE I

T. VAGINALIS INFECTIONS

\begin{tabular}{|c|c|c|c|c|}
\hline $\begin{array}{l}\text { Nature } \\
\text { of } \\
\text { Sample }\end{array}$ & $\begin{array}{c}\text { Total } \\
\text { No. of } \\
\text { Positive } \\
\text { Samples }\end{array}$ & $\begin{array}{c}\text { Positive } \\
\text { Smears and } \\
\text { Positive } \\
\text { Cultures }\end{array}$ & $\begin{array}{c}\text { Positive } \\
\text { Smears } \\
\text { and } \\
\text { Negative } \\
\text { Cultures }\end{array}$ & $\begin{array}{c}\text { Negative } \\
\text { Smears } \\
\text { and } \\
\text { Positive } \\
\text { Cultures }\end{array}$ \\
\hline $\begin{array}{l}354 \text { urethral } \\
\text { samples from } \\
200 \text { men }\end{array}$ & 90 & $62\left\{\begin{array}{l}69 \% \text { of } \\
\text { total } \\
\text { positive }\end{array}\right.$ & $17\left\{\begin{array}{l}19 \% \text { of } \\
\text { total } \\
\text { positive }\end{array}\right.$ & $11\left\{\begin{array}{l}12 \% \text { of } \\
\text { total } \\
\text { positive }\end{array}\right.$ \\
\hline $\begin{array}{l}378 \text { urine } \\
\text { samples from } \\
207 \text { men }\end{array}$ & 109 & $80(73 \%,)$, & $4(4 \%, \%)$ & $25(23 \%,)$, \\
\hline $\begin{array}{l}747 \text { vaginal } \\
\text { samples from } \\
563 \text { women }\end{array}$ & 165 & $129(78 \%,)$, & $6(4 \%,)$, & $30(18 \%,)$, \\
\hline $\begin{array}{l}225 \text { urine } \\
\text { samples from } \\
70 \text { women }\end{array}$ & 128 & $73(57 \%,)$, & $5(4 \%,)$, & $50(39 \%,)$, \\
\hline Total & 492 & $344(70 \%,)$, & $32(6 \cdot 5 \%,)$, & $116(23 \cdot 5 \%$, \\
\hline
\end{tabular}

It was found that species of Candida (Monilia) also grew well in this medium. Table II gives the results of comparing direct microscopic examination of wet smears with cultures in detecting Candida infections in the 563 women referred to in Table I.

TABLE II

CANDIDA INFECTIONS

\begin{tabular}{c|c|c|c|c}
\hline Sample & $\begin{array}{c}\text { Total } \\
\text { No. of } \\
\text { Positive } \\
\text { Samples }\end{array}$ & $\begin{array}{c}\text { Positive } \\
\text { Smears and } \\
\text { Positive } \\
\text { Cultures }\end{array}$ & $\begin{array}{c}\text { Positive } \\
\text { Smears } \\
\text { and } \\
\text { Negative } \\
\text { Cultures }\end{array}$ & $\begin{array}{c}\text { Negative } \\
\text { Smears } \\
\text { and } \\
\text { Positive } \\
\text { Cultures }\end{array}$ \\
\hline $\begin{array}{c}\text { 747 vaginal } \\
\text { samples from } \\
\text { 563 women }\end{array}$ & 91 & $34 \begin{array}{c}37 \% \text { of } \\
\text { total } \\
\text { positive } \\
\text { samples }\end{array}$ & 0 & $57 \begin{array}{c}63 \% \text { of } \\
\text { total } \\
\text { positive } \\
\text { samples }\end{array}$ \\
\hline
\end{tabular}

\section{Discussion}

As the tables show, the cultures provided a useful supplement to the examination of fresh smears in the routine diagnosis of $T$. vaginalis infections. In a few instances, negative cultures were obtained from samples in which trichomonads had been found in the fresh smears, but in many more cases the reverse obtained. This is particularly striking in the specimens of urine, in nearly one-third of which the diagnosis of trichomoniasis was based upon cultures.

Candida, when present in the fresh smears, always grew in the cultures, and in more than half the cases positive cultures were found although smears were negative. The presence of Candida did not interfere with the concomitant growth of trichomonads in the cultures.

Although no valid comparison can be made between the efficacy of the culture medium described in this paper and those previously used, because of the different techniques employed by other workers, the present medium has advantages which render it particularly suitable for diagnostic purposes. It supports a good growth of trichomonads; it is simple, cheap, easily made, and keeps for some time; and it can be used for the simultaneous detection of both $T$. vaginalis and Candida. A freeze-dried form of this medium may facilitate the preparation and storage of large quantities. The freeze-dried medium in individual tubes may be reconstituted with distilled water just before use. Feinberg (unpublished data) has found that this medium so dried and reconstituted will support the growth of laboratory strains of $T$. vaginalis.

\section{Summary}

A simple, cheap, and easily prepared culture medium is described for routine use in the clinical laboratory diagnosis of Trichomonas vaginalis and Candida infections.

A comparison of the examination of fresh smears and culturing in the medium described for detecting $T$. vaginalis infestations was made on 1,704 genito-urinary specimens, and for Candida on 747 specimens.

In the case of $T$. vaginalis a combination of the two methods gave the highest number of positive findings, but culturing was the more efficient single method. $T$. vaginalis would not have been detected in $23.5 \%$ of the samples had they not been cultured.

For the detection of Candida, culturing appears the better method. Sixty-three per cent. of the samples which were positive for Candida would 
have been dismissed as negative without it. For this organism, culturing alone appears sufficient.

The authors wish to thank the following members of the staff of the London Hospital for their help and advice: Mr. Victor Lack, Mr. A. J. King, Dr. I. N. O. Price, and Dr. C. S. Nicol. They are also grateful to the clinical, nursing, and laboratory staffs concerned for their willing co-operation. J. G. Feinberg is also indebted to Dr. Muriel Robertson, of the Lister Institute, for advice and guidance in the management of protozoal cultures.

\section{REFERENCES}

Andrews, M. N. (1929). J. trop. Med. Hyg., 32, 237.

Boeck, W. C., and Drbohlav, J. (1925). Amer. J. Hyg., 5, 371.

Feinberg, J. G. (1953). Nature (Lond.), 171, 1165.

Fischer, I. (1935). Pren. méd. argent., 22, 340.

Hawes, R. S. (1947). Quart. J. micr. Sci., 88, 79.

Jackson, M. H., Malleson, J., Stallworthy, J., and Walker, K. (1948). Problems of Fertility in General Practice, p. 46. Hamish Hamilton, London.

Johnson, G., and Trussell, R. E. (1943). Proc. Soc. exp. Biol. $(N . Y), 54,245$.

Lanceley, F. (1954). Brit. J. vener. Dis., 30, 163.

Lynch, K. M. (1915). Amer. J. trop. Dis., 2, 627.

McEntegart, M. G. (1952). J. clin. Path., 5, 275.

Reuling, F. (1921). Arch. Protistenk., 42, 347.

Sprince, H., and Kupferberg, A. B. (1947). J. Bact., 53, 435.

Whittington, M. J. (1951). J. Obstet. Gynaec. Brit. Emp., 58, 614. - (1957). Brit. J. vener. Dis., 33, 80. 